\title{
A Legal Proposition for a Regional Agreement to Protect Wildlife and Habitats in South Asia
}

\author{
Kokila Konasinghe ${ }^{1} \&$ Dulki Seethawaka ${ }^{2}$ \\ 1. Senior Lecturer, Department of Public and International Law, University of Colombo \\ 2. MPhil Candidate, Faculty of Law, University of Colombo
}

\begin{abstract}
South Asian countries are home to many species of wildlife given the different geographical landscapes spreading from the Himalayan mountains in Nepal to the oceans surrounding the Maldives and Sri Lanka. Illegal poaching of wildlife, destruction of habitats, and wildlife trade are only a few of the common threats found in the region. There are domestic legislations which protect the wildlife to a certain extent. However, there is no regional instrument which is capable of establishing a collective responsibility to care for and protect wildlife. As this geographical area of the world comprises mega-diverse ecosystems, the absence of a regional legal framework with the necessary legal protection of wildlife raises serious concerns. Therefore, this article first explores existing legal protection that has been granted to different types of wildlife at the domestic level. Next, to understand the significance of adopting a regional instrument which can establish a collective mechanism for protecting wildlife, it analyzes the regional agreements of the European Union (EU) as a case study. The article further examines the effectiveness of the laws of selected EU agreements with a view to their potential for developing a regional mechanism for South Asia.
\end{abstract}

\section{KEYWORDS:}

Wildlife, animal protection, South Asia, regional agreement, European Union, environmental law

Suggested Citation: Konasinghe, K. \& Seethawaka, D. (2021). A Legal Proposition for a Regional Agreement to Protect Wildlife and Habitats in South Asia. University of Colombo Review (New Series III), 2(2), 32 - 54.

(C) 2021 The Authors. This work is licenced under a Creative Commons Attribution 4.0 International Licence which permits unrestricted use, distribution, and reproduction in any medium, provided the original work is properly cited. 


\section{Introduction}

Wildlife and their habitats might be territorial; however, together they form a significant part of the global environment. Thus, the necessity of safeguarding them depends on domestic, regional, and international frameworks. When the threats against wildlife keep evolving, these frameworks should also adapt. The importance of protecting marine and terrestrial ecosystems are specified in the Sustainable Development Goals (SDGs) 14 and 15 respectively. SDG 14 on "Life Below Water" relates to the conservation and sustainable use of the oceans, seas, and marine resources (United Nations, 2021). Accordingly, the proper management of global marine resources is considered a key feature of a sustainable future (United Nations, 2021, para 2).

SDG 15, on the other hand, is on "Life on Land" and identifies the necessity for protecting, restoring, and promoting the sustainable use of terrestrial ecosystems, sustainable management of forests, combating of desertification, reversing of land degradation, and halting of biodiversity loss (United Nations, 2021). Both SDGs emphasize the need for protecting global ecosystems because many anthropocentric activities are rapidly destroying the environment and all its components. The Global Assessment Report of Biodiversity and Ecosystems Service 2019 states that nearly one million species of animals and plants are already threatened with extinction. (United Nations, 2021, para 2). Hence, there is a necessity to promote the sustainable use of all wildlife and their habitats.

South Asia is home to $15 \%$ of the biodiversity of the world, including diverse terrestrial, marine, and coastal ecosystems (Albertin, 2010, para 2). As recognised by an approved International Union for Conservation of Nature (IUCN) program (2017-2020), South Asia is one of the IUCN's eight Statutory Regions which requires the greatest conservation (IUCN, 2021, para 2). Two of the world's biodiversity hotspots are located in South Asia, namely the Himalayan Mountains, and the Western Ghats and Sri Lanka (Conservation International, 2021). There are also many protected areas including transboundary, sacred, and biodiverse landscapes and seascapes, biosphere reserves, wetlands, and key biodiversity areas (KBAs) dispersed throughout every nation in South Asia (IUCN, 2021, para 2). These ecosystems house a wide range of endemic floral and faunal species and habitats, and hence, the region is considered a repository of natural wealth.

The citizens of South Asian countries are extensively dependent on nature, which in turn exposes wildlife to a number of risks associated with human activities. Hence, the countries are continuously encouraged to enter into international and regional agreements, and execute domestic protective measures to conserve these valuable ecosystems of global significance. All South Asian countries are parties to the Convention on International Trade in Endangered Species of Wild Fauna and Flora (CITES) and the Convention on Biological Diversity (CBD) (CBD, 2012; CITES, 2021). Except for Bhutan and Nepal, the six other countries are parties to the Convention on the Conservation of Migratory Species of Wild Animals (CMS) (CMS, 2021). All South Asian member states, apart from Afghanistan and Maldives, are also parties to the Ramsar Convention (Ramsar, 2021). 
The existing regional agreements on wildlife conservation in South Asia are limited to the Declaration on South Asia Initiative for Combating Illegal Trade in Wildlife (the Jaipur Declaration) of 2008 (Declaration on South Asia Initiative for Combating Illegal Trade in Wildlife, 2008), and the South Asian Seas Action Plan 1995 (South Asian Seas Action Plan, 1995). There are also national legislations implemented to safeguard wildlife and their habitats. Despite these frameworks, the ecosystems in South Asia continue to be threatened by deforestation, habitat fragmentation, overexploitation, and pollution etc. (European Union, 2018, pp. 236-243; IUCN, 2021, para 5; Subramanian et.al, 2011, para 3). The upsurge in the occurrence of natural hazards and climate induced vulnerabilities further exacerbate the sensitive ecosystems (IUCN, 2021, para 5). Moreover, illegal poaching and wildlife trade directly affect valuable species of fauna and flora. Many charismatic species including the Royal Bengal Tiger, the Asian Elephant, the Asiatic Lion, the Snow Leopard, the Red Panda and the One-horned Rhino are listed as globally threatened species (IUCN Red List, 2021). This raises the question as to whether the existing legal instruments have been successful, or not, in conserving wildlife and habitats in South Asia.

This article is based on a study which investigated this concern by analyzing the domestic, regional, and global legislative frameworks which have been implemented to safeguard wildlife and its habitats in the South Asian Association for Regional Cooperation (SAARC) region. It also explores the importance of formulating a regional instrument to protect wildlife in South Asia, which can encourage countries to take individual and collective action, and especially acknowledge how collective approaches can also help safeguard each country's individual interests. In addition, it proposes recommendations as to the provisions that can be included in such a regional agreement. For this purpose, applicable legal instruments from the European Union (EU) which are specific to wildlife conservation were analyzed as a case study.

This research article was carried out using primary and secondary sources. A range of primary sources were examined, including applicable legislative instruments on wildlife protection at the domestic level, existing South Asian regional agreements - i.e., the Jaipur Declaration 2008 and the South Asian Seas Action Plan 1995 - and applicable regional instruments from the European Union including the Convention on the Conservation of European Wildlife and Natural Habitats 1979 by the Council of Europe, the Habitat Directive, the Birds Directive, and the Natura 2000 network. The article also briefly took into account the global instruments South Asian countries are currently parties to, namely, CITES, CBD, CMS, and Ramsar in order to identify whether there is a need of implementing regional protection for wildlife, without solely depending on international conventions. The secondary resources were based on reports by wildlife organizations, journal and newspaper articles, conference proceedings, and internet resources.

The article will first explore the scope of existing national legal protection and identify the present difficulties relating to wildlife conservation in each South Asian country. This will be helpful in recognising the common threats to wildlife conservation, a necessary first step in formulating regional agreements. The next section will critically analyze existing South Asian regional agreements designed for wildlife conservation. This 
is important to detect which common concerns relating to the protection and conservation of wildlife and habitats in South Asia have not been recognized in the regional agreements. Then the article will move forward to the case study of the EU to understand how regional instruments have incorporated collective responsibility towards wildlife conservation. Finally, recommendations will be discussed which would be applicable for the South Asian region in formulating a regional agreement to safeguard valuable wildlife and their habitats.

\section{A Critical Legal Analysis of the National Legislative Frameworks on Wildlife Conservation in South Asia}

\section{Afghanistan}

The Islamic Republic of Afghanistan is home to a variety of diverse wildlife including an estimated number of 137-150 mammal species, 428-515 bird species, 101-139 fish species, 92-112 reptile species and 6-8 amphibian species (CBD: Afghanistan, n. d., para 3 ). The forests of Nuristan, which are protected as a national park since 2020, are home to the most unique wildlife in the nation including four globally threatened mammals, i.e., the Asiatic Black Bear, the Markhor Goat, urial and other national animals of Afghanistan, and the Snow Leopard (Karlstetter, 2008, p. iii).

Under the Wildlife Conservation and Hunting Act 2001, wildlife habitats in Afghanistan are categorised into prohibited, permitted, sheltered and protected areas, and taking photographs, gathering information, and collecting samples of the wild fauna and flora in any of these areas are prohibited. The Ministry of Agriculture, Irrigation and Livestock holds the responsibility of issuing the lists of prohibited and permitted areas of hunting and animals. Hunting is banned in the areas under Emergency, the border's special zone, surrounding military areas, residential areas, hospitals, and resorts. Hunting methods using motorized vehicles, pits, explosives, toxic and chemical ingredients, mass hunting, and drying water to hunt aquatic animals are also forbidden (Wildlife Conservation and Hunting Act, 2001).

The Environment Law 2007 provides for a comprehensive 78 Articles relating to the protection and management of the environment, which are classified in 9 Chapters. Chapter 6 refers to biodiversity and natural resource conservation and management. Thereby, protected areas are classified into strict nature reserves, national parks, natural monuments, habitat/species management areas, protected landscapes and managed resource protected areas. Article 54 permits the international trade of selected species abiding by the provisions of the CITES. However, prior authorization in the form of a valid permit must be presented in both importing or exporting processes. Furthermore, the National Environmental Protection Agency (NEPA) is empowered to prepare the protected species list with the assistance of academics and relevant ministries (The Environment Law, 2007).

Despite these legal measures, there are concerns relating to wildlife conservation in Afghanistan due to deforestation, illegal poaching for food and trade, and land encroachment (Kanderian et al., 2011, para 1). The forest cover of Nuristan has been disappearing at an 
alarming rate over the past two decades, endangering the lives of many species (Handwerk, 2011). Other major risks are the ongoing security conflicts, which usually take place in the regions harboring the most valuable habitats (NEPA, 2019, p. 11; Handwerk, 2011).

\section{Bangladesh}

Nearly $80 \%$ of the land in Bangladesh consists of floodplains and wetlands, thus providing a massive natural resource base for rare wildlife and flora (SACEP: Bangladesh, 2021, para 2). According to the CMS National Report (2019), the biodiversity in Bangladesh varies over an approximate number of 130 species of mammals, 710 bird species, 164 species of reptiles, and 56 species of amphibians. The country also provides a key wintering area for migratory birds along the Central Asian and East Asia-Australasian Flyways (CMS National Report, 2019, para 3; Reza \& Hasan, 2019, para 12). However, 219 species from those counted in the CMS National Report are threatened. (CMS Report, 2019, para 4).

There are a number of acts and policies related to wildlife conservation and protection in Bangladesh. These are, the Wildlife (Conservation \& Security) Act 2012, the Environment Conservation Act 1995, the Forest Act 1927 (amended in 2000), the National Environment Policy 2018, the Ecologically Critical Areas Management Rules 2016, the Environment Conservation Rules 1997, and the Forest Policy 1994 (CMS National Report, 2019, p.7).

The Wildlife (Conservation \& Security) Act 2012, which replaced the Bangladesh Wildlife (Preservation) Order of 1973, provides for important provisions on protecting wildlife. Chapter II relates to the appointment of a Wildlife Advisory Board which is empowered with many duties and functions. Other chapters include comprehensive specifications on protecting wild animals and plants; determining vulnerable, endangered, and critically endangered species; removing and releasing of wild animals; prohibited actions related to sanctuary; issuing of licences for wild animals; importing, exporting, and re-exporting of wild animals; and offences and penalties. The Act further provides for specific sections to regulate the penalties for killing tigers and elephants (section 36), cheetah, lam cheetah, hoolock, sambar deer, crocodile, gharial, whale or dolphin (section 37 ), and birds and migratory birds (section 38) (Wildlife (Conservation \& Security) Act, 2012).

Similar to other countries of the region, Bangladesh faces a number of threats to its forests and wildlife from hunting and poaching, the local and international wildlife trade, the human-wildlife conflict, and habitat degradation and fragmentation (Reza \& Hasan, 2019). The high demand for animal body parts of the illegal medicine trade in China has increased illegal poaching and hunting of flagship species of Bangladesh (Reza \& Hasan, 2019). The construction of new roads under global development strategies such as the Belt and Road initiative by China, is also predicted to further endanger the habitats and lives of tigers (Kimbrough, 2020, para 1-3). 


\section{Bhutan}

The Kingdom of Bhutan contains high diversity and density of various species of wild fauna and flora due to its landscape range which varies across six major agroecological zones from the lowlands to alpine forests (CBD: Bhutan, n. d., para 1). The Royal Manas National Park harbors many rare animals belonging to both tropical and subtropical ecosystems (Tourism Council of Bhutan, 2021, para 1). Some of the prominent species include the Royal Bengal Tiger, the Asian Elephant, the One-horned Indian Rhinoceros, the Clouded Leopard, the Himalayan Black Bear and the Gangetic Dolphin (Tourism Council of Bhutan, 2021, para 5).

The Forest and Conservation Act of Bhutan 1995 is the primary legal instrument which regulates the use of private and public forests and the conservation of forests, wild fauna and flora, soil and water resources. The Act includes 46 sections under nine chapters, of which Chapter 3 lays out the prohibited acts in government reserved forests, and explicitly forbids setting of fire, except controlled campfires, and the burning of lime and/or charcoal. Protected areas are specified in Chapter 4, and Chapter 7 is dedicated to the conservation of wildlife (Forest and Conservation Act of Bhutan, 1995).

The Forest and Nature Conservation Rules of Bhutan 2006 also emphasize wildlife conservation in Chapter 7. Compared to the Act of 1995, these rules are elaborative and include provisions such as the protection of wildlife (both totally protected species and other species), prohibition of activities such as killing, hunting, possession, and captive breeding of wild animals; and the permission of certain traditional uses of wild plants and animals as well as permitted killing or removal of wild animals due to a threat of harm to people or property (The Forest and Nature Conservation Rules of Bhutan, 2006).

Apart from the above, there are also other legislative instruments which safeguard wildlife such as the Protection of Wildlife and Protected Areas Law No. 6/94 which deals with the protection of ecosystems in the country including the wild and endangered species of both fauna and flora (Protection of Wildlife and Protected Areas Law No. 6/94, 1994); Rules on Biological Corridors, 2006 which is on the conservation and management of biological corridors between protected areas for safe wildlife movement (Rules on Biological Corridors, 2006); and the National Environment Protection Act, 2007.

Key issues related to wildlife in Bhutan, which are also observed in other countries of the region, include land conversion and deforestation for development projects, local and international wildlife trade, population growth and rapid urbanisation, and local consumption (CBD: Bhutan, n. d., para 4). Forest fires in Bhutan are a major concern for the country, with 1,403 forest fire incidents recorded in less than a decade (Wangmo, 2020, para 1).

\section{India}

The biggest and most diverse nation in the region, India, comprises many different landscapes across the country which are abundant in floral and faunal diversity. As per the National Biodiversity Action Plan of 2019, India is home to 3364 species of fish, 414 amphibian species, 584 reptile species, 1340 bird species, and 427 mammal species. 
(Ministry of Environment, 2019, p. 31) Some of the endangered wild animals in India include the Asiatic Lion, the Royal Bengal Tiger, the Snow Leopard, the One-horned Rhinoceros, the Nilgiri Tahr, the Kashmiri Red Stag, the Blackbuck, the Indian Vulture, the Lion-tailed Macaque, and the Gangetic Dolphin (Sinha, 2020).

The Indian Wildlife (Protection) Act 1972 emphasizes the protection of wild flora and fauna and interprets "animal" to include amphibians, birds, mammals, and reptiles. Chapter 3 regulates the hunting of wild animals, prohibiting any person from hunting endangered wild animals except for special cases as mentioned under Section 12 (The Indian Wildlife (Protection) Act, 12, 1972). Permits for hunting are granted for the purpose of education, scientific research and management, specimen collection, and manufacturing of life saving drugs. However, the non-listed wild animals are deemed to be hunted without any restriction (The Indian Wildlife (Protection) Act, 12, 1972).

Section 39 of the Act declares all wild animals to be the property of the government, which is significant (The Indian Wildlife (Protection) Act, 39, 1972). Any hunted animal or article thereby belongs to the government. The Act was amended in 2006 to safeguard endangered species with special reference to tigers. Accordingly, Chapter 4B sets up the National Tiger Conservation Authority with many duties and powers relating to the conservation of the remaining population of tigers in India (The Indian Wildlife (Protection) Act, IVB, 1972), and Chapter 4C relates to the constitution of the Tiger and other Endangered Species Crime Control Bureau, its powers, and its functions (The Indian Wildlife (Protection) Act, IVC, 1972).

Wildlife in India is threatened with destruction of habitats, illegal wildlife trade and poaching, development projects and urbanisation, over-exploitation of resources, environmental degradation, and pollution and desertification (CBD: India, n. d., para 12). Studies show that over $75 \%$ of the habitats of the Himalayan region have been destroyed due to overgrazing, land conversion, and fuelwood and fodder collection (World Wildlife Fund, 2021, para 1). It is also observed that the illegal wildlife trade, which constantly threatens endangered species in India, is towards meeting the demands of the international market (World Wildlife Fund, 2021, para 1).

\section{The Maldives}

The Maldives is home to a diverse marine ecosystem spread across 1192 coral islands and is considered one of the most delicate environments in the world (SACEP: Maldives, 2021, para 1; Ministry of Environment and Energy, 2015, p. 15). The coral reef ecosystem of the Maldives is the seventh largest reef system, forming $3.14 \%$ of the world's reef area (SACEP: Maldives, 2021, para 3). Nearly 2041 distinct coral reefs have been identified which safeguard an array of marine wildlife (SACEP: Maldives, 2021, para 3). Additionally, more than 167 species of birds of which the majority are migratory, and 5 endemic species have been identified (Ministry of Environment and Energy, 2015, p. 15).

The legal framework on protecting the biodiversity of the Maldives concentrates on preserving the maritime zone. The Fisheries Act of the Maldives, Act No.14 was enacted in 2019 with the intention of sustainably managing fisheries and marine resources, and their ecosystems in the country. The Act imposes many safety measures to ensure sustainable 
fishing methods and the protection of marine resources (The Fisheries Act of the Maldives, Act No.14, 2019).

However, the marine environment of the Maldives faces constant threat from the impacts of climate change, tourism, land reclamation projects, and over-exploitation, while its terrestrial biodiversity is threatened by poor waste management, pollution, and unsustainable development and agricultural practices (CBD: Maldives, 2021, para 6). The impacts of climate change endanger marine biodiversity in the Maldives in many ways. The rise of sea water temperature can harm the sensitive coral reefs and result in coral bleaching. Furthermore, the rise of sea levels can cause sea erosion and the destruction of coastal biodiversity and mangroves (Fardeen, 2019, para 9).

There is a growth of land reclamation projects in the Maldives under which the lagoons have expanded in size to create artificial islands which are often converted into tourist hotels and resorts (Varanasi, 2020). Tourism and fisheries are considered the two main sources of income for the country. However, the current situation is that tourism and over-exploitation of marine resources are becoming major problems (Russell, 2018). The increasing levels of plastic debris which are released to the ocean also pose threats to aquatic wildlife (Russell, 2018).

\section{Nepal}

Nepal has diverse ecosystems enriched with remarkable biodiversity and habitats due to its unique landscape of mountains, gorges, valleys, and plains (Paudel et al, 2011, para 1). Even though the highest number of endemic faunal species can be seen within its highlands, the wetlands of Nepal are also of utmost importance, and have gained international recognition (CBD: Nepal, 2021, para 1). There are nine wetlands recognised as Ramsar sites, of which $68.2 \%$ and $31.6 \%$ are, respectively, in the Terai and High Himalaya regions (CBD: Nepal, 2021, para 1). These wetlands harbor about 193 species of birds and 185 freshwater fish and some of them are considered as critically endangered species (CBD: Nepal, 2021, para 3).

The most popular national park of the country is the Sagarmatha National Park, which is formed of glaciers, valleys, mountains, and Mount Everest, the highest peak in the world. Species which are common in the mountains of India and Bhutan, such as the Snow Leopard and the Red Panda can be observed in this national park (UNESCO, 2021, para 1).

The national framework on the conservation of wildlife in Nepal is based on the National Parks and Wildlife Conservation Act 2029 (1973). This Act oversees the management of national parks, and the protection of wildlife and habitats by incorporating restrictions on hunting and regulating permitted actions in protected areas. It thereby prohibits the hunting of any wild animal and damage to forest resources, including wildlife and birds in any national park or reserve, without obtaining written permission from authorized officers (National Parks and Wildlife Conservation Act 2029, 1973).

Similar to the biodiversity concerns of other countries in the region, Nepal faces threats of deforestation and forest fires through overexploitation, including overgrazing and overharvesting, product extraction, illegal trade and poaching, habitat destruction, pollution, 
and an unregulated tourism industry (CBD: Nepal, 2021, paras 5-6). Deforestation in Nepal has been a serious issue in recent times. In 2020, it was reported that $2.3 \mathrm{kha}$ of natural forest cover out of 4.80Mha (as was reported in 2010) had been lost within a span of 10 years (Global Forest Watch, 2021). Yet another major threat is forest fires which are seasonal between March and April (Voiland, 2021, para 1). The fires that took place in 2021 are considered the most extreme in recent times, with disastrous consequences (Aljazeera, 2021, para 1).

\section{Pakistan}

Pakistan owns a variety of ecosystems such as mountains shared with Afghanistan's borders, deserts divided with India, midlands enriched with rain forests, mangroves of the Indhu-Burma delta, and coral reefs alongside the Balochistan coast (CBD: Pakistan, 2021, para 1). The approximate numbers of species identified in the country consist of 195 mammals (6 endemic), 177 reptiles (13 endemic), 22 amphibians (9 endemic), 198 freshwater fish (29 endemic), and 668 bird species of which 25 are considered endangered (CBD: Pakistan, 2021, para 1).

Wildlife conservation in Pakistan is considered a provincial responsibility and is, therefore, incorporated into many provincial acts of the Punjab, Balochistan, Islamabad, Azad Jammu \& Kashmir, Sindh, and the Northern and West Frontier Provinces (NWFP) (Shafiq, 2005). This is significant since each of these acts and ordinances refer to specific conservation issues in each province while addressing common concerns. Some of these acts are being amended to include new regulations such as the Sindh Wildlife Protection, Preservation, Conservation and Management Bill 2020 which aims to ban all hunting of wild animals (Mandhro, 2020, para 1). Previously, hunting on private property was permitted within the Sindh and the NWFP provinces (Shafiq, 2005), and the new Bill proposes to repeal this law.

Pakistan's National Biodiversity Strategy and Action Plan (NBSAP) was approved in 2015. It focuses on protecting and conserving the environment and wildlife, while ensuring the sustainable use of natural resources. The Plan was incorporated through the combined efforts of the forestry wing of Pakistan's Ministry of Climate Change and the International Union for Conservation of Nature (IUCN) together with provincial forest, water, environment, and wildlife experts in the country (Jaffery, 2018).

Common concerns are environmental pollution, poaching and hunting, overgrazing, deforestation, harvesting, destruction of habitats, and desertification (CBD: Pakistan, 2021, para 2; Mustafa, 2019, para 4). Reports indicate that Pakistan ranks as the second highest country for deforestation globally (CBD: Pakistan, 2021, para 2). The hunting of game birds during migration, which is permitted particularly in the Sindh province, is another concern for environmentalists. At present, excessive hunting has endangered the populations of both local and migratory birds (Rizvi, n.d.). It should also be noted that there are constant conflicts taking place between the borders of India and Pakistan, particularly over Kashmir, and between Afghanistan and Pakistan, where wild animals crossing the borders travel through unsafe forest corridors (Karlstetter, 2008). 


\section{Sri Lanka}

Sri Lanka hosts a variety of ecosystems including coral reefs, seagrass meadows, mangroves, river lagoons, mud flats, grasslands, rainforests, and mixed evergreen forests (SACEP: Sri Lanka, 2021, paras 2-3). These ecosystems provide homes for many species of fauna with high levels of endemicity. Sri Lanka has, thereby, claimed the title of a Biodiversity Hotspot together with the Western Ghats of India (MoMD\&E, 2016, p. 25).

The presence of megafauna such as the Asian Elephant, the Leopard, and the Sloth Bear is considered a hallmark of Sri Lanka's biodiversity (MoMD\&E, 2016, p. 25). In the Asian continent, Sri Lanka has the highest density of elephants. The Sri Lankan Elephant is recorded as the largest of the three subspecies among the Asian elephants (Mombauer, 2018, para 10). The nation is widely known for its diverse marine ecosystem and habitats as well. Among the eight marine turtles existing in the world, five can be found in its southwestern and south-eastern beaches (Lakpura, 2021).

The predominant ordinance on the protection of wildlife in Sri Lanka is the Fauna and Flora Protection Ordinance No. 2 of 1937. It provides guidance on safety measures which can be taken to protect wildlife in natural reserves and sanctuaries, and prohibited activities in these areas. Furthermore, there is special reference to protecting elephants, buffaloes, vertebrates, and invertebrates in any area outside a national reserve or a sanctuary. Other domestic laws are the Forest (Amendment) Act No. 65 of 2009 (in which the protection of wildlife is briefly mentioned), the National Wilderness Heritage Act No. 3 of 1988, the Fisheries and Aquatic Resources Act No. 2 of 1996, the Coast Conservation Act 57/1981 (amended by Act 49.2011), and the National Environmental Act No. 47 of 1980 which impose various rules and regulations pertaining to the conservation of Sri Lanka's ecosystems and biodiversity.

The citizens of Sri Lanka are dependent on animals for various cultural, religious, symbolic, economic, and environmental pursuits. However, during recent times, there are many instances of human-wildlife conflicts occurring on a daily basis (Mombauer, 2020, para 3). The main reasons for such conflicts are deforestation, land encroachment, habitat degradation, increasing human density, and pollution (Mombauer, 2020, para 5).

Analyzing each country's profile in terms of species diversity, challenges to wildlife conservation, and existing national, regional and international frameworks is helpful for several observations. The South Asian region is blessed with a variety of wildlife and habitats from the snow mountains of the Himalayas to the depths of the Indian Ocean surrounding the Maldives and Sri Lanka. Some of these species are of utmost importance due to their endemic nature and being categorised as vulnerable or critically endangered. The regional or global extinction of such important species would affect all biodiversity, ecosystems, and communities in the long run. Therefore, it is important to take appropriate steps to ensure their safety and sustainability. In this regard, it is also necessary to understand the scope of protection granted for South Asian wildlife and habitats by regional and international agreements as discussed in the next section. 


\section{A Critical Analysis of the Regional Instruments on Wildlife Conservation in South Asia}

As was previously mentioned, the regional agreements on wildlife conservation are limited to the Jaipur Declaration 2008 and the South Asian Seas Action Plan 1995. The Jaipur Declaration focuses on mitigating wildlife trade in the region (SACEP, 2021) and introduced the South Asia Initiative for Combating Illegal Trade in Wildlife and Regional Action Plan and the Formation of South Asia Wildlife Enforcement Network (SAWEN) (SACEP, 2021). All SAARC nations are parties to the Declaration.

The South Asian Seas Action Plan 1995 aims to protect the marine environment in the region and is adopted by the five nations which have ocean borders, namely Bangladesh, India, Maldives, Pakistan, and Sri Lanka (SACEP, 2021, para 1). The action plan includes integrated coastal zone management and the protection of the marine environment from land-based activities among others (SACEP, 2021, para 2).

The rainforests, deserts, glaciers, corals, mangroves, and grasslands belonging to all types of geographical elevations are found within the region and they are connected to each other, forming a single ecological space (Saran, 2021, para 5). These natural assets are sometimes shared between the Member States and sometimes treated individually. Accordingly, collective management of these ecosystems is necessary for the betterment of citizens and biodiversity. This can be approached by implementing a regional instrument. The IUCN recognizes, moreover, that in order to successfully conserve biodiversity and duly manage the ecosystems, it is essential to maintain cross-border collaborations and participation (IUCN, 2021, para 5). However, the regional agreements in South Asia on the protection of wildlife are limited to two specific areas, namely illegal wildlife trade and marine creatures. Many other concerns are left unaddressed. This is a major drawback in the regional conservation effort.

The concerns on wildlife conservation in South Asia can be categorised into two sections. On the one hand, internal issues such as habitat loss, over-exploitation, deforestation, human-wildlife conflict, pollution, and illegal poaching require each nation to take necessary domestic action to safeguard its wildlife and their habitats. These actions include duly enforcing existing legal regulations, implementing stringent legal provisions, appointing state authorities to enforce laws, being authoritative in state development projects, empowering the judiciary, and incorporating local measures for wildlife conservation. However, as per the legal analysis, it is evident that the countries in the region act differently, and manage internal threats to wildlife in varying degrees. On the other hand, external issues such as the illegal wildlife trade, impacts of climate change, protection of migratory species and trans-boundary species, and the invasion of alien species require South Asian nations to build regional cooperation and implement a collective approach. However, these concerns are not addressed in the existing regional agreements. 


\section{A Critical Analysis on the International Instruments on Wildlife Conservation in South Asia}

All South Asian nations are parties to the Convention on International Trade in Endangered Species of Wild Fauna and Flora (CITES) which ensures that the international trade of wild faunal and floral specimens does not endanger the survival of species. This also applies to the Convention on Biological Diversity (CBD) which aims to conserve biological diversity, promote sustainable use of the components of biological diversity, and ensure fair and equitable sharing of the benefits arising out of the utilization of genetic resources (CBD, 2012; CITES, 2021).

Except for Bhutan and Nepal, the other six South Asian countries are parties to the Convention on the Conservation of Migratory Species of Wild Animals (CMS) which specializes in the conservation of migratory species, migrations routes, and habitats (CMS, 2021). All South Asian Member States apart from Afghanistan and the Maldives are parties to the Ramsar Convention which focuses on the conservation of wetland ecosystems (Ramsar, 2021).

These Conventions have been ratified by enacting relevant domestic regulations. The main concern in relation to international conventions is that the same convention is not uniformly implemented in domestic legislation. For instance, in an article titled "Towards Informed and Multi-faceted Wildlife Trade Interventions", Challender et al. analyze the effectiveness of CITES and refer to several important factors. They identify that some developing countries have failed to enact necessary legislation to implement CITES and that the effectiveness of the Convention is hampered by international issues relating to governance, state-society, culture, and enforcement capacity. The enforcement of CITES is also affected by internal conflicts and insufficient border controls, poor domestic trade controls, corruption, collusion, under-sourcing of wildlife agencies, lack of priority to wildlife concerns and failure to recognise illegal trade as a serious crime (Challender et al., 2015, p. 139). Yet another example is that CITES does not provide a conclusive list of all traded endangered species of wildlife found in the South Asian region. This was also noted in an article titled "A Case Study on Illegal Reptile Poaching from Balochistan, Pakistan" in which the authors identified that the endangered reptiles of Pakistan are not included in CITES (Masroor et al., 2020, p. 73). Masroor, Khisroon and Jablonski also noted that "the CITES only regulate the trade of fewer than $8 \%$ of worldwide recognised reptile species; therefore, trade in the vast majority of species is not monitored or regulated. On the other hand, $45 \%$ of the world's reptile species have been assessed by the IUCN. Wildlife trade regulations by countries may offer protection to the CITES-listed species but all the nonCITES species are left to endure the terrible consequences of high-value illegal wildlife trade" (p. 73). Therefore, it is evident that the South Asian countries cannot solely depend on international conventions to safeguard their wildlife and habitats. Even though these international instruments enforce a certain level of protection to the wildlife in South Asia, the species diversity and the common concerns are better dealt with in a regional rather than a global context. 
As per the International Law principle of state sovereignty, however, a regional agreement cannot interfere with the sovereignty of a state (Besson, 2011, para 1). Therefore, in recommending a regional agreement, this article does not imply challenging state sovereignty. It merely suggests establishing a better legal framework which can provide powerful recommendations to Member States. These recommendations may not be legally binding. However, if a Member State refuses to oblige, then that Member State might be subject to certain disadvantages in diplomatic and international relations with implications on regional foreign policy, investment agreements, and peace negotiations etc. (Farida, 2015, para 3). Therefore, a regional agreement must be authoritative enough to oblige Member States to take necessary steps to protect and conserve their wildlife and natural habitats by establishing collective as well as individual responsibility.

In order to identify which provisions can be included in such a regional agreement, we next discuss a regional instrument from another part of the world which can provide guidance in formulating an instrument for the protection of wildlife and their habitats in the South Asian region.

\section{Lessons Learnt from the European Union Regional Framework on Wildlife Conservation}

\section{The Bern Convention (Convention on the Conservation of European Wildlife and Natural Habitats, 1979)}

The Bern Convention is significant because it promotes cooperation between the signatory countries in conserving European wildlife and their natural habitats as well as protecting endangered and vulnerable migratory species. The Convention lists the Strictly Protected Species in Appendix 2 and the Protected Fauna species in Appendix 3. Furthermore, Appendix 4 specifies prohibited means and methods of killing, capture, and other forms of exploitation of wild fauna (Bern Convention, IV, 1979).

Under Article 3, Member States are required to consider conservation of wild species and their habitats by taking necessary steps to promote national policies, undertake development and planning policies and measures against pollution, and promote education and dissemination of general information. Endemic species which are considered either endangered or vulnerable, as well as endangered habitats, must be given special attention by each contracting party (Bern Convention, 3, 1979).

It is also obligatory to take appropriate and necessary legislative and administrative measures to conserve the wild faunal species listed in Appendix 2 (Bern Convention, II, 1979). Accordingly, Article 7 prohibits any deliberate capture, keeping and killing, damage to, or destruction of, breeding sites; disturbance during breeding, rearing, and hibernation periods; destruction or taking of eggs; and possession of, and internal trade of, living or dead animals (Bern Convention, 7, 1979).

Migratory species in the region are protected under Article 10, under which the Member States must coordinate necessary protection measures for the migratory species listed in Appendices 2 and 3, which may cross territories (Bern Convention, 10, 1979). 
Article 14 appoints the Standing Committee, which is empowered to review the provisions, and make any relevant recommendations for the purpose of proper implementation of the Convention (Bern Convention, 14, 1979). Accordingly, the Standing Committee decided to maintain a case-files system, which is a monitoring tool that allows private citizens and NGOs to submit complaints on possible breaches of the Convention (Council of Europe, n.d.). Even though it is not related to any provision in the Convention, this is considered a very successful problem-solving instrument. As per the Register of Bern Convention Complaints prepared by the Directorate of Democratic Participation which was published on 8th September 2021, a total of 206 complaints have been considered by the Standing Committee since 1982 (Directorate of Democratic Participation, 2021).

Following the Bern Convention, a number of supplementary Declarations have been implemented such as the Pisa Declaration on Protected Areas (2015), the Larnaca Declaration on Illegal Killing of Birds (2011), and the Declaration on Working together for Biodiversity, Protection of Natural Areas and Fight Against Climate Change (2010) (European Commission, 2021). This shows that appropriate steps are being taken to respond any further developments relating to the Convention without undue delay.

\section{The Habitats Directive}

Formerly known as the Council Directive 92/43/ECC on the conservation of natural habitats and of wild fauna and flora, the Habitats Directive was adopted in 1992 with the foremost intention of maintaining biodiversity while fulfilling the economic, social, cultural, and regional necessities of communities. Article 23 of the Directive requires the 27 Member States to enforce laws, regulations, and administrative provisions necessary to comply with the Directive within two years of such notification (Habitats Directive, 23, 1992).

Compared to the Bern Convention, the Habitats Directive is more comprehensive in nature. It lists over 1000 faunal and floral species and about 200 habitats. Accordingly, Annex 1 lists out a variety of protected habitats (Habitats Directive, I, 1992), and Annex 2, 4 and 5 refer to animals and plants notification (Habitats Directive, 1992). Annex 6 provides for the prohibited methods of capturing, killing, and transporting of animals (Habitats Directive, VI, 1992).

For the species mentioned in Annex 2, core areas of their habitats are selected as Sites of Community Importance (SCIs) which must be managed in keeping with their ecological needs. These habitats are included in the Natura 2000 Network. Stringent protection is required for the species in Annex 4, which should be applicable within and outside the Natura 2000 areas, covering their entire natural distribution within the region (Habitats Directive, IV, 1992). Therefore, Article 12 prohibits the deliberate capture and killing; causing disturbance during breeding, rearing, and hibernation periods; destroying or taking of eggs; destroying breeding sites; and keeping, transporting, and selling of these species. (Habitats Directive, 12, 1992). For the species in Annex 5, Member States are required to certify that their exploitation, and taking of specimens, are subject to proper management practices (Habitats Directive, V, 1992). 
Supplementary documents are published to ensure that the Member States can implement the provisions in the Directive without any misapprehensions, which is an important initiative for other regional instruments as well. The "Interpretation Manual of European Union Habitats - EUR28" provides for a common definition for all types of habitats and helps to interpret Annex 1. Yet another example is the "Guidance document on the strict protection of animal species of Community interest under the 'Habitats' Directive 92/43/EEC", which specifically focuses on the implementation of Articles 12 and 16 of the Directive (European Commission, 2021).

\section{The Birds Directive}

Even though there are around 500 species of wild birds in the European Union, it is considered that about $32 \%$ of this number is not subject to proper conservation. Therefore, the main intention of the Birds Directive is to provide appropriate protection for all of the 500 wild birds that are found naturally in the region, with special reference to threatened and migratory birds. After being amended in 2009, this Ordinance is formerly known as the Directive 2009/147/EC on the Conservation of Wild Birds (European Commission, 2021).

The Directive specially concentrates on the protection of migratory and threatened species of birds. For the threatened species listed in Annex 1, Member States must identify Special Protection Areas (SPAs) (Birds Directive, I, 2009). Annex 2 permits 82 species of birds to be hunted, subject to the restriction of not hunting them in their most vulnerable circumstances (Birds Directive, II, 2009). Annex 3 specifies 26 species which can be used in activities such as deliberate killing, capturing, trading, and destroying of their nests, which are otherwise considered as forbidden (Birds Directive, III, 2009). Annex 4 allows for sustainable management of the hunting of certain species but bans non-selective and mass killing of birds through methods which are specified (Birds Directive, IV, 2009).

These selected European legislative frameworks emphasize the concern and efforts of developed countries in protecting their wildlife and habitats. They have not only taken legislative measures at both national and regional levels, but also moved beyond to incorporate more community engagement through online platforms. This is commendable, especially during periods of pandemic such as the current context.

We next discuss how a regional framework inspired by EU legislation can be customized to protect the wildlife and habitats of South Asia and provide recommendations for a South Asian regional framework.

\section{Recommendations for a Regional Agreement to Protect Wildlife and Habitats in South Asia}

As was previously noted, the necessity of implementing a regional agreement is to form an authority which can provide powerful recommendations to Member States on wildlife conservation. It is essential to appoint a Standing Committee representing all Member States to administer the proper application of the regional instrument. As was observed in the Bern Convention, the powers of the Standing Committee must not be limited in the Convention; the Standing Committee must instead be given the opportunity 
to incorporate and decide upon necessary steps as per the requirements. Furthermore, this Standing Committee must be authorized to intervene in any instance of complaint made by any Member States, individuals, or NGOs. Its recommendations may not be legally binding but Member States must abide by them in order to maintain diplomatic relations.

There are many domestic regulations designed to protect wildlife in South Asia, but these are not properly implemented. This could be the result of government agents not performing their statutory duties, lack of resources and knowledge, and political interference. Therefore, as established by Article 3 of the Bern Convention, the proposed agreement for South Asia should mandate that the governments of Member States acknowledge the importance of preserving the environment, and take necessary action in enforcing existing legal safeguards. The agreement can also oblige Member States to repeal long-standing acts and ordinances and replace them with more applicable statutes with timely provisions. It was observed in the country profile analysis that although there is national legislation which attempts to protect wildlife and prohibit certain actions which can harm the fauna and their habitats, certain groups still engage in illegal activities. This indicates that some provisions in the existing laws as well as mechanisms are not adequate. A regional instrument might have a better chance of ensuring that governments enact the necessary statutes, since it would recommend both individual and collective responsibility.

It is also important to study the common concerns of the region, as well as the loopholes in national legislative frameworks while preparing the document because the regional instrument can be used to provide necessary remedies. Common concerns among the Member States need to be addressed broadly in a regional context, and necessary institutions which can actively participate in regional cooperation must be established.

The instrument must be capable of evolving without a time-consuming process and must be duly amended in order to meet timely changes. If such a provision is difficult to incorporate, an initiative such as passing subsequent declarations as was observed in the Bern Convention, is recommended. It is also necessary to provide supplementary documents with guidance on the application of certain provisions which need the special attention of the Member States.

Furthermore, it can list out the endangered and vulnerable species in each country and categorize them as strictly protected and protected species. If certain species of animals are considered "regionally protected", this would trigger each national legal regime to focus on incorporating its own frameworks without further delay. This would be helpful in the conservation efforts of trans-boundary ecosystems, and for combating the illegal trade in wildlife. It will grant special protection to land-based animals that cross territorial boundaries and critically endangered wildlife which are common in more than one country such as the Indus and Ganges Dolphins, the Royal Bengal Tigers, the Asian Elephants, the One-horned Rhino, and the Snow Leopard.

Finalizing a "regionally protected list" may seem a difficult initiative in practical terms. However, this type of list has already been incorporated in the Bern Convention. Therefore, if carefully prepared, such a list would enable a closer watch over endangered species and their habitats. This would be advantageous, particularly in ensuring that 
national governments do not initiate mass development projects within the most valuable wild habitats. Governments can bypass this list by engaging in projects that are eco-friendly and not destructive.

Similar to the protected areas noted in the EU legislative framework, the new regional agreement for South Asia can specify a Protected Areas List where all development or urbanization projects with, or without the permission of particular governments, is prohibited, and any state or private person who is accountable for any destruction can be made liable. If a government fails to enforce the laws against such an entity or an individual who has destroyed an ecologically important area, the regional agreement can exercise authoritative powers and mandate that government to take necessary actions. This can be further enhanced by specifying an inclusive list of Prohibited Actions relating to both protected species and protected areas in the regional agreement.

The regional instrument must also allow the general public and NGOs from Member States to lodge complaints if there are any disputes regarding any development projects which are likely to destroy or cause harm to protected areas and wildlife. For instance, there are development projects currently taking place which are causing considerable damage to the environment in Member States with the support of current governments. There is no administrative authority which stops such projects and makes governments accountable for their actions. Such actions will be restricted to a certain extent if governments are regionally noticed and held liable.

This instrument can also encourage the exchange of information, technology, and knowledge among the Member States in protecting wildlife and habitats, and establish collaborative efforts within the Member States, leaving aside their differences. The Member States can propose a regional institution which would gather all necessary information that can be accessed online. Its website can be used, as in the Natura 2000 Network, for the maintenance of data and maps, for overlooking designated sites and their management, and provide for communication platforms. An administrative department specifically concerned with the protection of wildlife and their habitats can also be introduced as a regional front representing all South Asian countries. The active participation of all stakeholders in Member States must be encouraged, since the protection of the environment and ecosystems is no longer the responsibility of an individual or a specific government. Rather than mandating that governments take actions on this, the regional front can directly address the issues. A dispute resolution mechanism can also be introduced which will simplify the process of settling differences, for instance in implementing trans-boundary conservation efforts and curbing the illegal trade in wildlife.

\section{Conclusion}

South Asia is blessed with an abundance of wildlife and habitats, constituting a rich biodiversity within the region. This regional biodiversity, whether it is land-based, coastal, or marine ecosystems, cannot be separated by geographical boundaries. The Member States share a single ecological space which necessitates a holistic approach to conserve biodiversity and protect wildlife. Nor is it possible for cross-border issues such as the 
wildlife trade, climate change, and ecological degradation to be resolved through a domestic legislative framework alone. Hence, there is a compelling need for regional cooperation to collectively nurture and manage these natural assets. The countries must set aside their political tensions and rivalry in the economic and commercial spheres, and facilitate collaborative mechanisms to mitigate any further adverse impacts to the biodiversity of the region. Therefore, South Asia needs a joint front to combat biodiversity destruction which can only be accomplished by a regional agreement to protect and conserve its wildlife and habitats.

i. The implementation of the Habitats and Birds Directives is often referred to with the Natura 2000 Network, which is considered the world's largest coordinated network of protected areas. It is applicable to all $27 \mathrm{EU}$ Member States, both on land and at sea. This is not a legislative instrument but rather a network which is designed to protect vulnerable and threatened species and habitats in the European Union that are listed in both the Habitats and the Birds Directives. Hence, the network maintains data and maps, overlooks designated sites and their management, provides communication platforms, and organizes Natura 2000 awards and an EU Natura 2000 Day (European Commission, 2021).

\section{References}

Albertin, C. (2010). South Asia: Combating illegal wildlife trade. United Nations Office on Drugs and Crime. https://www.unodc.org/southasia/frontpage/2010/April/wildlife-crime.html

Al Jazeera. (2021, April 9). Nepal battles worst forest fires in years as air quality drops. https://www. aljazeera.com/news/2021/4/9/nepal-battles-worst-forest-fires-in-years-as-air-quality-drops

Besson, S. (2011). Sovereignty. Oxford Public International Law. https://opil.ouplaw.com/ view/10.1093/law:epil/9780199231690/law-9780199231690-e1472

Challender, D. W. S., Harrop, S. R., \& MacMillan, D. C. (2015). Towards informed and multifaceted wildlife trade interventions. Global Ecology and Conservation, 3, 129-148. https://doi. org/10.1016/j.gecco.2014.11.010

Coast Conservation Act 57/1981 (Lk.).

Conservation of Migratory Species National Report: Bangladesh. (2019). 13th Meeting of the Conference of the Parties to Convention on the Conservation of Migratory Species of Wild Animals (COP13).

Convention on Biological Diversity. (1992). https://www.cbd.int/doc/legal/cbd-en.pdf

Convention on Biological Diversity. (n.d.). Afghanistan - Main Details. https://www.cbd.int/ countries/profile/?country=af\#facts

Convention on Biological Diversity. (n.d.). Bhutan - Main Details. https://www.cbd.int/countries/ profile/?country=bt\#facts 
Convention on Biological Diversity. (n.d.). India - Main Details. https://www.cbd.int/countries/ profile/?country=in

Convention on Biological Diversity. (n.d.). Maldives - Main Details. https://www.cbd.int/countries/ profile/? country $=\mathrm{mv}$

Convention on Biological Diversity. (n.d.). Nepal - Main Details. https://www.cbd.int/countries/ profile/?country $=\mathrm{np}$

Convention on Biological Diversity. (n.d.). Pakistan - Main Details. https://www.cbd.int/countries/ profile/?country $=\mathrm{pk}$

Convention on Biological Diversity. (n.d.). Sri Lanka - Main Details. https://www.cbd.int/countries/ profile/?country=lk

Convention on International Trade in Endangered Species of Wild Fauna and Flora (CITES). (n.d.). What is CITES? https://cites.org/eng/disc/what.php

Convention on International Trade in Endangered Species of Wild Fauna and Flora, March 3, 1973. https://cites.org/eng/disc/text.php

Convention on the Conservation of Migratory Species of Wild Animals, June 23, 1979. https://www. cms.int/en/convention-text

Convention on the Conservation of Migratory Species of Wild Animals. (n.d.). CMS. https://www. cms.int/en/legalinstrument/cms

Convention on Wetlands of International Importance especially as Waterfowl Habitat, February 2, 1971. https://www.ramsar.org/sites/default/files/documents/library/current_convention_text_e. pdf.

Council of Europe. (n.d.). Bern Convention; Convention on the Conservation of European Wildlife and Natural Habitats. https://www.coe.int/en/web/bern-convention/reporting.

Declaration on South Asia Initiative for Combating Illegal Trade in Wildlife (Jaipur Declaration) 2008, May 22, 2008. Annex XVII. GC 11. SACEP. http://www.sacep.org/pdf/Declarations/03. Jaipur-Declaration-on-South-Asia-Initiative-for-Combating-Illegal-Trade-in-Wildlife-of-2008. pdf.

Directorate of Democratic Participation. (2021). Register of Bern Convention Complaints. https:// rm.coe.int/case-files-register-2021/1680a171a3.

Ecologically Critical Areas Management Rules 2016 (Bd.).

Environment Conservation Act 1995 (Bd.).

Environment Conservation Rules 1997 (Bd.).

Environment Law 2007 (Afg.).

European Commission. (2021). Natura 2000.

https://ec.europa.eu/environment/nature/natura2000/index_en.htm. 
European Commission. (2021). Species Protection.

https://ec.europa.eu/environment/nature/conservation/index_en.htm.

European Commission. (2021). The Birds Directive.

https://ec.europa.eu/environment/nature/legislation/birdsdirective/index_en.htm.

European Commission. (2021). The Habitats Directive.

https://ec.europa.eu/environment/nature/legislation/habitatsdirective/index_en.htm.

European Union. (2018). \#3 South Asia. Larger than Tigers - Inputs for a strategic approach to biodiversity conservation in Asia - Regional reports. 210-291.

European Union, Convention on the Conservation of European Wildlife and Natural Habitats 1979, OJ L 38, 10.2.1982, p. 3-32. https://eur-lex.europa.eu/legal-content/EN/TXT/ PDF/?uri=CELEX:21979A0919(01)\&from=EN.

European Union, Council Directive 92/43/ECC on the conservation of natural habitats and of wild fauna and flora, 1992, L 206, 22/07/1992 P. 0007 - 0050.

https://eur-lex.europa.eu/legal-content/EN/TXT/?uri=CELEX:31992L0043.

European Union, Directive 2009/147/EC on the conservation of wild birds, 2009, OJ L 20, 26.1.2010, p. 7-25.

https://eur-lex.europa.eu/legal-content/EN/TXT/PDF/?uri=CELEX:32009L0147\&from=EN.

Fardeen, M. (2019). Climate Change and its effects on the Maldives. https://storymaps.arcgis.com/stories/a8f8b5b0477f458ea70826756b46a 275.

Farida, M.A. (2015). The Regional Integration: The Impact and Implications in Member States' Sovereignty. https://medium.com/pangripta-loka/the-regional-integration-the-impact-andimplications-in-member-states-sovereignty-5679ebe0990

Fauna and Flora Protection Ordinance No.2 of 1937 (Lk.).

Fisheries Act of the Maldives Act No.14 (Mv.).

Fisheries and Aquatic Resources Act No.2 of 1996 (Lk.).

Forest (Amendment) Act No.65 of 2009 (Lk.).

Forest Act 1927 (Bd.).

Forest and Nature Conservation Rules of Bhutan 2006 (Bt.).

Forest Policy 1994 (Bd.).

Global Forest Watch. (2021). Nepal.

Handwerk, B. (2011). Afghanistan Bright Spot: Wildlife Surviving in War Zones. https://www. nationalgeographic.com/adventure/article/110711-afghanistan-animals-bears-wolvesenvironment-science-war.

International Union for Conservation of Nature. (2021). Commission on Ecosystem Management; South Asia. https://www.iucn.org/commissions/commission-ecosystem-management/regions/ south-asia. 
IUCN Red List. (2021). Critically Endangered.

https://www.iucnredlist.org/search/list?taxonLevel=Amazing\&searchType=species.

Jaffery, R. (2018, December 01). Pakistan's Biodiversity is Disappearing, But No One Seems to Notice. The Diplomat. https://thediplomat.com/2018/12/pakistans-biodiversity-is-disappearingbut-no-one-seems-to-notice/.

Kanderian, N., Lawson, D., Zahler, P. (2011). Current status of wildlife and conservation in Afghanistan. International Journal of Environmental Studies, 68(3), 281-298. https://www. tandfonline.com/doi/abs/10.1080/00207233.2011.573960?journalCode=genv20.

Karlstetter, M. (2008). Wildlife Surveys and wildlife conservation in Nuristan, Afghanistan including Scat and Small Rodent Collection from Other Sites. Wildlife Conservation Society/ United States Agency for International Development, Afghanistan Biodiversity Conservation Program.

Kimbrough, L. (2020, May 21). Tigers threatened by a vast network of planned roads across Asia. Mongabay. https://news.mongabay.com/2020/05/tigers-threatened-by-a-vast-network-ofplanned-roads-across-asia/.

Lakpura. (n.d.). Aquatic Life. https://lakpura.com/pages/aquatic-life.

Mandhro, S. (2020, July 30). New Law enhances protection for wildlife. The Express Tribune. https://tribune.com.pk/story/2257352/new-law-enhances-protection-for-wildlife.

Masroor, R., Khisroon, M., \& Jablonski, D. (2020). A case study on illegal reptile poaching from Balochistan, Pakistan. Herpetozoa, 33. 67-75. https://herpetozoa.pensoft.net/article/51690/ element $/ 8 / 104016 / /$.

Ministry of Environment and Energy. (2015). National Biodiversity Strategy \& Action Plan. https:// www.cbd.int/doc/world/mv/mv-nbsap-v2-en.pdf.

Ministry of Environment, Forest and Climate Change. (2019). Implementation of India's National Biodiversity Action Plan - An Overview - 2019. https://www.cbd.int/doc/world/in/in-nbsapother-en.pdf

Ministry of Mahaweli Development and Environment. (2016). National Biodiversity Strategic Action Plan 2016 - 2022. https://www.cbd.int/doc/world/lk/lk-nbsap-v2-en.pdf.

Mombauer, D. (2018, October 05). Beleaguered Biodiversity: Protecting Sri Lanka's Unique Wildlife. https://www.slycantrust.org/post/beleaguered-biodiversity-protecting-sri-lankasunique-wildlife.

Mombauer, D. (2020, July 22). Sri Lanka: Rich in biodiversity, and human-wildlife conflict. Mongabay. https://news.mongabay.com/2020/07/sri-lanka-rich-in-biodiversity-and-humanwildlife-conflict/.

Mustafa, W. (2019, May 20). Pakistan has a chance to reverse biodiversity loss. Khaleej Times. https://www.khaleejtimes.com/editorials-columns/pakistan-has-a-chance-to-reversebiodiversity-loss. 
National Environment Policy 2018 (Bd.).

National Environment Protection Act 2007 (Bt.).

National Environmental Protection Agency. (2019). Afghanistan's 6th National Report to the United Nation's Convention on Biological Diversity. https://www.cbd.int/doc/nr/nr-06/af-nr-06en.pdf

National Environmental Act No.47 of 1980 (Lk.).

National Parks and Wildlife Conservation Act 2029 (1973) (Np.).

National Wilderness Heritage Act No.3 of 1988 (Lk.).

Paudel, P.K., Bhattarai, B.P., Kindlmann, P. (2011). An Overview of the Biodiversity in Nepal. In Kindlmann, P (Eds.), Himalayan Biodiversity in the Changing World. (1-40). Springer, Dordrecht. https://link.springer.com/chapter/10.1007/978-94-007-1802-9_1\#citeas.

Protection of Wildlife and Protected Areas Law No. 6/94 (Bt.).

Ramsar. (2021). The Convention on Wetlands and Its Mission. https://www.ramsar.org/about/the-convention-on-wetlands-and-its-mission.

Reza, A.A., Hasan, M.K. (2019). Forest Biodiversity and Deforestation in Bangladesh: The Latest Update. https://www.intechopen.com/books/forest-degradation-around-the-world/forestbiodiversity-and-deforestation-in-bangladesh-the-latest-update.

Rizvi, A.A. (n.d.). Wiping out from the wild. http://www.wildlifeofpakistan.com/Features/wipingoutfromthewild.htm.

Rules on Biological Corridors 2006 (Bt.).

Russell, M. (2018, May 5). Conservation in the Maldives. The Maldives Expert. https://www.themaldivesexpert.com/1729/conservation-in-the-maldives/.

Saran, S. (2021). South Asia needs a united voice at UN climate, biodiversity meetings. https:// blogs.worldbank.org/endpovertyinsouthasia/south-asia-needs-united-voice-un-climatebiodiversity-meetings.

Shafiq, M. M. (2005). Wildlife Acts \& Rules of Pakistan. https://countrysafeguardsystems.net/sites/ default/files/AJK\%20Wildlife_acts_and_rules.pdf.

Sindh Wildlife Protection, Preservation, Conservation and Management Bill 2020 (Pk.).

Sinha, V. (2020, May 15). National Endangered Species Day 2020: Here are 7 endangered animal species in India. India Today. https://www.indiatoday.in/education-today/gk-current-affairs/ story/national-endangered-species-day-2020-here-are-7-endangered-animal-species-inindia-1678339-2020-05-15.

South Asia Co-operative Environment Programme. (2008). South Asian Seas Programme - Action Plan. http://www.sacep.org/programmes/south-asian-seas/action-plan\#: :text=The\%20 Action\%20Plan\%20for\%20the,Delhi\%2C\%20on\%20March\%2024th\%201995. 
South Asia Co-operative Environment Programme. (2008). The Jaipur Declaration. http://www.sacep.org/pdf/Declarations/03.Jaipur-Declaration-on-South-Asia-Initiative-forCombating-Illegal-Trade-in-Wildlife-of-2008.pdf.

South Asia Co-operative Environment Programme. (2021). Bangladesh. http://www.sacep.org/member-countries/bangladesh.

South Asia Co-operative Environment Programme. (2021). Maldives. http://www.sacep.org/ member-countries/maldives.

South Asia Co-operative Environment Programme. (2021). Sri Lanka. http://www.sacep.org/ member-countries/sri-lanka.

Subramanian, S.M., Gasparatos, A., Braimoh, A.K., Elliott, W. (2011). Unraveling the drivers of Southeast Asia's biodiversity loss. https://unu.edu/publications/articles/unraveling-the-driversof-southeast-asia-biodiversity-loss.html\#info.

The Forest and Conservation Act of Bhutan 1995 (Bt.).

Tourism Council of Bhutan. (2021). Royal Manas National Park. https://www.bhutan.travel/national-park/royal-manas-national-park.

UNESCO. (2021). Sagarmatha National Park. https://whc.unesco.org/en/list/120/.

United Nations. (2021). Sustainable Development Goals; 14 Life Below Water. https://www.un.org/sustainabledevelopment/oceans/.

United Nations. (2021). Sustainable Development Goals; 15 Life on Land. https://www.un.org/sustainabledevelopment/biodiversity/.

Varanasi, A. (2020). How corruption, tourism, environmental sustainability play out in paradise. https://www.devex.com/news/how-corruption-tourism-environmental-sustainability-play-outin-paradise-97678.

Voiland, A. (2021). A Fierce Fire Season in Nepal. https:/earthobservatory.nasa.gov/images/148185/a-fierce-fire-season-in-nepal.

Wangmo, C. (2020, January 11). Bhutan's forest (coniferous) prone to fire. Kuensel. https://kuenselonline.com/bhutans-forest-coniferous-prone-to-fire/.

Wildlife (Conservation \& Security) Act 2012 (Bd.).

Wildlife Conservation and Hunting Act 2001 (Afg.).

Wildlife (Protection) Act 1972 (Ind.).

World Wildlife Fund. (2021). Causes of Habitat Loss.

https://wwf.panda.org/discover/knowledge_hub/where_we_work/eastern_himalaya/threats/ habitat_loss/.

World Wildlife Fund. (2021). Illegal Wildlife Trade in India. https://www.wwfindia.org/about_wwf/enablers/traffic/illegal_wildlife_trade_in_india/. 